\title{
GENETIC DIVERSITY AMONG BOTRYOSPHAERIA ISOLATES AND THEIR CORRELATION WITH CELL WALL-LYTIC ENZYME PRODUCTION
}

\author{
Roze L. Saldanha ${ }^{1 *}$; José E. Garcia ${ }^{2}$; Robert F. H. Dekker ${ }^{2}$; Laurival A. Vilas-Boas ${ }^{1,3}$; Aneli M. Barbosa ${ }^{2 *}$ \\ ${ }^{1}$ Universidade Estadual de Londrina, Centro de Ciências Biológicas, Departamento de Biologia Geral, Londrina, PR, Brasil; \\ ${ }^{2}$ Universidade Estadual de Londrina, Centro de Ciências Exatas, Departamento de Bioquímica e Biotecnologia, Londrina, PR, \\ Brasil; ${ }^{3}$ Universidade Federal da Bahia, Departamento de Biologia Geral, Salvador, BA, Brasil
}

Submitted: November 23, 2006; Returned to authors for corrections: February 08, 2007; Approved: March 19, 2007.

\begin{abstract}
Nine isolates of Botryosphaeria spp. were evaluated for their growth and the production of cell wall-lytic enzymes (laccase, pectinase and $\beta$-1,3-glucanase) when grown on basal medium in the absence and presence of the laccase inducer, veratryl alcohol (VA). The genetic relationship among the nine isolates collected from different host plants was determined by RAPD analyses. ITS sequence analysis showed eight closely related isolates classified as Botryosphaeria rhodina, and one isolate classified as Botryosphaeria ribis. RAPD analysis resolved the isolates into three main clusters based upon levels of laccase and $\beta$-1,3-glucanase activity. There appears to be no correlation between pectinase production and genetic diversity among the nine isolates. However, the strain characterized as B. ribis, positioned out of the main cluster, was found to be the highest producer of pectinases in the presence of VA.
\end{abstract}

Key words: Botryosphaeria isolates; ITS and RAPD; Laccase; Pectinase; $\beta$-1,3-Glucanase

\section{INTRODUCTION}

Fungi belonging to the genus Botryosphaeria (Botryosphaeriaceae, Dothideomycetes, Ascomycota) are plurivorous phytopathogens colonising a wide range of host plants of agricultural, forestry, ecological and economic importance, causing diseases, and are widely distributed worldwide in temperate and tropical climatic regions. As plant pathogens, the Botryosphaeria species primarily direct their attack on the plant cell wall by producing key enzymes associated with its hydrolysis (9).

An isolate of Botryosphaeria (MAMB 05) characterised as $B$. rhodina has been extensively studied in our laboratory regarding its production of laccases and exopolysaccharides. As a ligninolytic ascomycete, this fungal isolate produced only one kind of polyphenol oxidase, a laccase ( $p$-diphenol:dioxygen oxidoreductase, EC 1.10.3.2) (4) whose production could be enhanced above constitutive levels in the presence of the inducer, veratryl alcohol (VA) (8). Laccases are multi-copper oxidases widely distributed among fungi associated with wood- decay, basidiomycetes and ascomycetes alike, and are involved in plant pathogenesis (16). B. rhodina isolate MAMB 05 also produced the cell wall-lytic enzymes, pectinase (2) and $\beta-1,3-$ glucanase (11), recognised as playing a role in pathogenesis in plants and fungi, as virulence factors.

Identification of species in the genus Botryosphaeria is complicated on several aspects. Morphological diversity among teleomorphs is often insufficient to allow identification at the species level, and species identification is based upon morphological characteristics of the anamorphs; the most common form of Botryosphaeria (10). Sequencing of the ITS region of rDNA has been extensively used in inter- as well as intra- specific comparisons of fungi (7). Sequence analysis of the ITS region alone (15), or in combination with sequences from others regions (22), have made a significant contribution to resolving taxonomic problems in the genus Botryosphaeria, and have been used to study relationships among species and to distinguish closely-related Botryosphaeria spp. (3).

Random amplified polymorphic DNA (RAPD) has been used extensively as genetic markers in different fungal species aimed

*Corresponding Author. Mailing address: Depto de Bioquímica e Biotecnologia, CCE, Universidade Estadual de Londrina, Caixa Postal 6001, CEP 86051-990 - Londrina - PR, Brazil. Tel.: (43) 3371-4270 ou (43) 3371-4054. E-mail: aneli@uel.br 
at establishing a correlation between genetic diversity, and strain identification and differentiation (14). Consequently, RAPD has been used to demonstrate relationships among pathogenicity in Botryosphaeriaceae strains from different geographical locations (25).

A wide variety of commercial fruits and vegetables are subject to attack by pathogenic microorganisms including Botryosphaeria species that cause rots and spoilage. A characteristic of microbial spoilage of fruit is usually indicative of pectinolytic activity (20) as fruits are rich in pectins. Several Botryosphaeria isolates obtained from rotting fruit and vegetables and identified by morphological characteristics as Lasiodiplodia theobromae (the anamorphic form of B. rhodina), and other plant hosts (B. rhodina and B. ribis), were evaluated for their genetic diversity using RAPDs. In addition, the cell wall-lytic enzymes (laccase, pectinase and $\beta$-1,3-glucanase) were examined when the fungal isolates were grown under similar physiological conditions in attempts to determine a relationship between the genetic diversity of these pathogenic isolates and "pathogenicity-related" enzyme production.

\section{MATERIALS AND METHODS}

\section{Botryosphaeria isolates}

Botryosphaeria rhodina (isolate MAMB 05) was obtained from a stem canker on an eucalypt tree (4). B. ribis (EC 01) was isolated from Eucalyptus citriodora, and L. theobromae (MC 01) from currupixá wood (Micropholis spp.) (21). Six isolates of fungi morphologically identified as $L$. theobromae from different fruits and vegetables were obtained from Pernambuco (Brazil): MMLR (orange, Citrus sp.); MMGR (graviola Annona muricata); MMPI (pinha, A. squamosa); MMBJ (eggplant, Solanum sp.); MMMFR and MMMFO (mango, Mangifera sp., fruit and leaf, respectively).

\section{Culture conditions}

Fungal isolates were maintained through periodic transfer on potato-dextrose-agar at $4^{\circ} \mathrm{C}$. Inoculum was prepared by growing the Botryosphaeria isolates on glucose-agar plates (8). Fungal cultures were grown in submerged liquid cultivation at $28^{\circ} \mathrm{C}$ and $180 \mathrm{rpm}$ for $4.5 \mathrm{~d}$ in baffled Erlenmeyer flasks containing basal medium (Vogel minimal salts medium (29) and glucose (10 g/l) as carbon source, $\mathrm{pH}$ 6.0) (8). In the laccase induction experiments, veratryl alcohol was added to the basal medium prior to inoculation at a concentration of $30.4 \mathrm{mM}$ (27). All experiments were carried out in replicates of 4 , and the results represent the mean value $\pm \mathrm{SD}$.

\section{Species identification based on sequencing of the ITS1-5.8S- ITS2 regions of rDNA}

Fungal genomic DNA was extracted according to the protocol of Bogo et al. (6). DNA quantification was performed according to Sambrook and Russel (19). PCR reactions were carried out in a final volume of $25 \mu \mathrm{l}$ containing 5 - $25 \mathrm{ng}$ of template; $10 \mathrm{mM}$ Tris- $\mathrm{HCl}$ (pH 9.0); $50 \mathrm{mM} \mathrm{KCl} ; 2 \mathrm{mM} \mathrm{MgCl}_{2}$; $0.2 \mathrm{mM}$ of each dNTP; $0.6 \mu \mathrm{M}$ of each primer; and $1 \mathrm{U}$ of Taq DNA polymerase (Invitrogen, Brazil). DNA primers were used in the forward, ITS1 (5'-TCCGTAGGTGAACCTGCGG-3') and reverse, ITS4 (5'-TCCTCCGCTTATTGATATGC-3') directions (30). The amplifications were performed in a Thermocycler (PTC 100. MJ Research, Waltham, MA, USA) and programmed for an initial denaturation of $4 \mathrm{~min}$ at $92^{\circ} \mathrm{C}$, followed by 35 cycles of 1 min at $95^{\circ} \mathrm{C}, 30 \mathrm{sec}$ at $57^{\circ} \mathrm{C}$ and $1 \mathrm{~min}$ at $72^{\circ} \mathrm{C}$, and a final extension of $5 \mathrm{~min}$ at $72^{\circ} \mathrm{C}$. The amplified product was precipitated with 7.5 $\mathrm{M}$ ammonium acetate (0.1 volume) and absolute ethanol (3 volumes), and recovered in $10 \mu \mathrm{l}$ of ultrapure water.

Precipitated PCR fragments were sequenced in the forward and reverse directions with a MegaBace 1000 Sequencer (Amersham Biosciences, Piscataway, NJ, USA) using primers ITS1 and ITS4. Analyses of sequence quality and the construction of the consense sequence were performed using Phred/Phrap/Consed software (12), and compared to sequences in the GenBank database using BLASTn as a search tool (1). The criterion used for species identification was based on the best score verified. Alignments were performed using BioEdit $\mathrm{v}$ 5.0.9 (13) and Clustal X (26). Sequences were manually adjusted to facilitate the analysis.

\section{RAPD analysis}

DNA was used as template for RAPD-PCR using the primers OPW2, OPW4, OPW5, OPW12, OPW14, OPX9, OPX13, OPX14 (Operon Technologies, Alameda, USA). PCR reactions were performed in a final volume of $10 \mu \mathrm{l}$ containing 1-10 ng of genomic DNA, $0.5 \mu \mathrm{M}$ of primer, $0.1 \mathrm{mM}$ dNTPs (Eppendorf, Hamburg, Germany), $1.5 \mathrm{mM} \mathrm{MgCl} 2$ and $1 \mathrm{U}$ of Taq DNA polymerase (Invitrogen, Brazil). Reactions were done in a T1 Thermocyler (Biometra, Göttingen, Germany) set to the following conditions: $92^{\circ} \mathrm{C}$ for $3 \mathrm{~min} ; 40$ cycles each of $40 \mathrm{~s}$ at $92^{\circ} \mathrm{C}, 1.5 \mathrm{~min}$ at $40^{\circ} \mathrm{C}$ and $5 \mathrm{~min}$ at $72^{\circ} \mathrm{C}$, followed by a final amplification period at $72^{\circ} \mathrm{C}$ for $7 \mathrm{~min}$. At least two separate amplifications were conducted for each fungal isolate. Amplicons were separated by electrophoresis in $2 \%$ agarose gels (19). Gels were stained with ethidium bromide. The Jaccard similarity index (23) was used to construct a pairwise similarity matrix, which was used to perform hierarchical cluster analyses based upon the unweighted pairgroup method with arithmetic mean (UPGMA) using NTSYS software version 1.30 (18).

\section{Analytical techniques}

Extracellular fluid (ECF) was obtained after removal of the mycelium by centrifugation ( $30 \mathrm{~min}$ at $1250 \mathrm{x} \mathrm{g}$ ) and used as the source of enzyme. Laccase activity was assayed against ABTS (Sigma; 2.2 ${ }^{1}$-azino-bis(3-ethyl-benzthiazoline-6-sulfonic acid)) at $\mathrm{pH} 3.0$ and $50^{\circ} \mathrm{C}(4)$, and expressed in units as $\mu$ mol oxidized 
product formed $/ \mathrm{min} / \mathrm{ml}$ of enzyme. Pectinase and $\beta-1,3$ glucanase activity were determined using citrus pectin (Sigma; $10 \mathrm{~g} / \mathrm{l}$ ) and laminarin (Sigma; $4 \mathrm{~g} / \mathrm{l}$ ) as respective substrates at $\mathrm{pH} 5.0$ and $50^{\circ} \mathrm{C}$, and measured the reducing sugars produced (24). The unit of pectinase and $\beta$-1,3-glucanase activity are defined as the number of $\mu \mathrm{mol}$ reducing sugars produced/min/ $\mathrm{ml}$ under the standard assay conditions.

\section{RESULTS AND DISCUSSION}

Optimal fungal growth was previously established with $B$. rhodina (isolate MAMB 05) under non-induced (basal medium, no inducer) and induced (VA) conditions (27), and was used to grow the Botryosphaeria isolates in this study. All Botryosphaeria isolates grew on basal medium producing similar amounts of mycelial biomass.

PCR consistently produced a single amplification product of approximately $510 \mathrm{bp}$. It was possible to determine a $505 \mathrm{bp}$ length sequence corresponding to the $18 \mathrm{~S}$ partial sequence, the ITS1, 5.8S and ITS 2 complete sequence, and the $28 \mathrm{~S}$ partial sequence. Comparison of the sequence of Botryosphaeria isolate MAMB 05 with sequences deposited in GenBank showed a score between 914 and 971 , with $99 \%$ similarity to $B$. rhodina and its anamorph, $L$. theobromae. The comparison of the sequence data strongly suggested that Botryosphaeria isolate MAMB 05 extensively studied by our group was $B$. rhodina. Isolates morphologically classified as $L$. theobromae were confirmed as $B$. rhodina by ITS comparison with sequences in GenBank. Similarly, ITS analysis also confirmed B. ribis.

The comparative analysis of the ITS1-5.8S-ITS2 sequences among all of the $B$. rhodina isolates showed high nucleotide similarity among them when compared to that identified as $B$. ribis. An intra-specific variation of $1.2 \%$ was observed between isolate MAMB 05 and all of the isolates from the fruits and vegetables examined, especially positioned at the $18 \mathrm{~S}$ and ITS 1 region. The majority of substitutions $(83.33 \%)$ was observed for isolate MMMFO (leaf of mango tree), and only one substitution was observed for the sequence from isolate MMBJ (eggplant). The nucleotide changes comprised one transition at the $18 \mathrm{~S}$ fragment, three at the ITS1 and two transversions at the $18 \mathrm{~S}$ and ITS1, respectively.

The inter-specific variation was from $16.67 \%$ with 16 transitions (one at the 5.8S), 19 transversions distributed over the ITS1, ITS2 and 28S fragments, and two small deletions (two nucleotides each) at the ITS1 (all $B$. rhodina isolates) and the ITS2 (only B. ribis EC 01). Two important deletions, of approximately 24 and $17 \mathrm{bp}$, were observed between positions $67 / 91$ and 98/113, respectively. This deletion was observed in all of the $B$. rhodina isolates and was found to be conserved in all of the B. rhodina and L. theobromae sequences deposited in GenBank, but were not observed in the Botryosphaeriaceae family (data not shown). This deletion should be considered an important characteristic in discriminating the $B$. rhodina isolates from the other Botryosphaeria species.

Laccase production commenced by $48 \mathrm{~h}$ when the $\mathrm{C}$ source (glucose) was near-depleted from the culture medium and was accompanied by a fall in $\mathrm{pH}$ to 4.2 (8). Results for laccase production by all of the Botryosphaeria isolates examined are shown in Fig. 1a. Basal laccase levels (no inducer), albeit low, were highest for isolate MAMB 05 followed by MMLR (orange) and MC 01 (currupixa wood). B. ribis was a poor producer of laccase as confirmed in an earlier study (28). Under induced conditions, laccase activity could be increased up to 60 -fold by the addition of VA to the basal medium with highest enzyme titres produced by isolate MMLR, which was some 1.5-fold higher than isolates MAMB 05 and MC 01 (Fig. 1a).

Previous studies (2) demonstrated that isolate MAMB 05 was pectinolytic and produced pectinase when grown on glucose as sole carbon source. The pectinolytic nature of other Botryosphaeria species was first reported in B. ribis (17). In the present study, all Botryosphaeria isolates grown on basal medium produced pectinase constitutively (Fig. 1b) indicating that all of the isolates were pectinolytic. In the presence of VA, the pectinase titres decreased except for B. ribis, which increased 3-fold under the conditions of cultivation. The decreased enzyme activities were due to VA repressing the synthesis of pectinase $(2,9)$. In the case of $B$. ribis it appears, in contrast to the $B$. rhodina isolates studied, where the cell wall-degrading enzymes were repressed by VA that VA appeared to de-repress the synthesis of pectinase. How this occurs is not yet understood,

B. rhodina isolate MAMB 05 was previously demonstrated to produce $\beta$-1,3-glucanase when cultured on the substrate botryosphaeran (5), but also produced $\beta$-1,3-glucanase when grown on basal medium (11). In the present work, all of the Botryosphaeria isolates examined produced $\beta$-1,3-glucanase with highest enzyme titres produced by $B$. ribis (Fig. 1c). All Botryosphaeria isolates with the exception of MMMFR (mango fruit) and MMMFO produced higher $\beta$-1,3-glucanase levels than isolate MAMB 05. When the Botryosphaeria isolates were cultured under conditions for inducing laccase, the $\beta-1,3-$ glucanase levels decreased for all isolates (MMMFO was an exception), in agreement with previous findings that VA repressed the synthesis of polysaccharide-degrading enzymes (9).

Ninety-one loci were observed showing $81.95 \%$ polymorphism. Although isolate MAMB 05 showed low variation at the ITS sequence compared to the other $B$. rhodina isolates, at the RAPD clustering, however, it was positioned out of the main group, showing $25 \%$ genetic similarity with the other B. rhodina isolates (Fig. 2). Comparison of the RAPD profiles with the ITS sequences suggests that the isolates examined can have a common genetic basis, with low variation at conserved regions, in spite of the high variability observed by RAPD analysis. ITS and RAPD analyses did not show any 


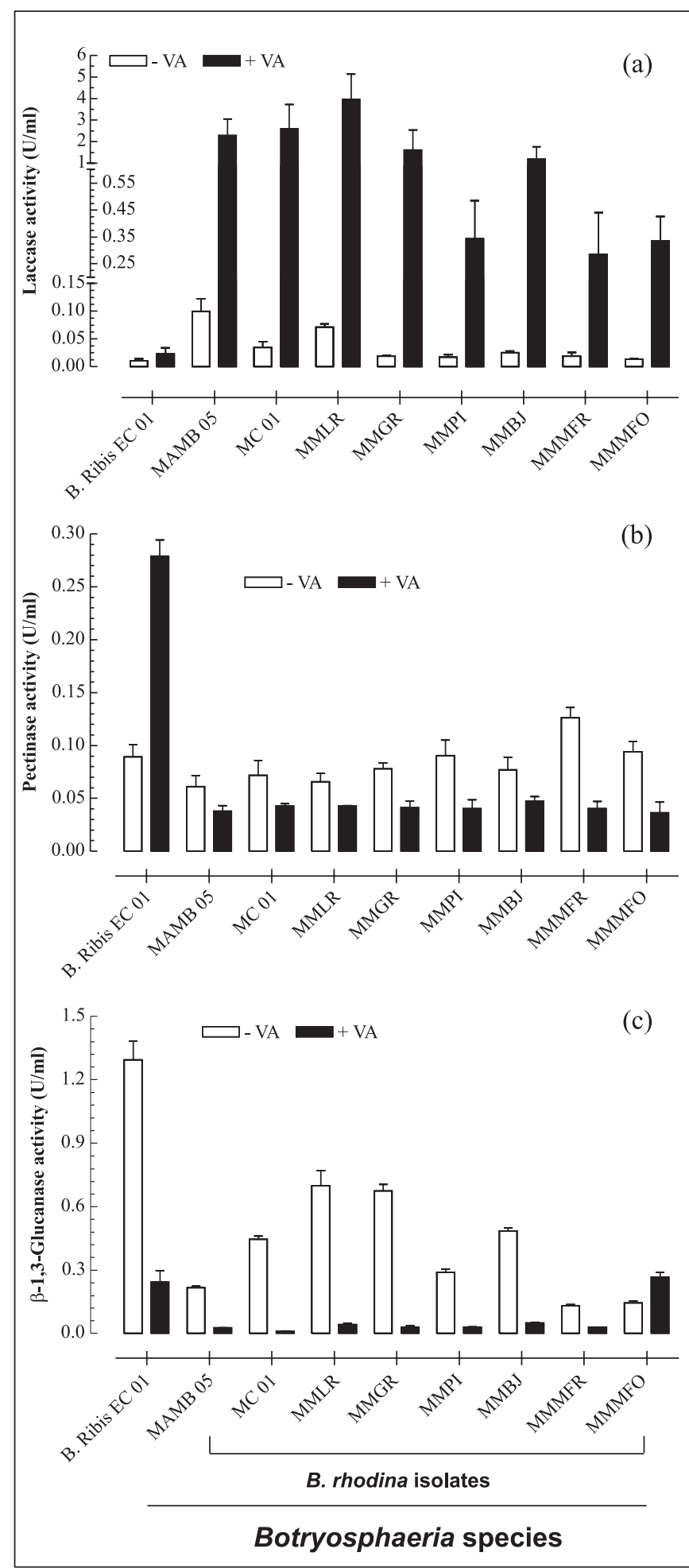

Figure 1. Comparison of the production of cell wall-lytic enzymes: (a) laccase, (b) pectinase and (c) $\beta$-1,3-glucanase by Botryosphaeria isolates grown on basal medium in the absence and presence of the laccase inducer, VA.

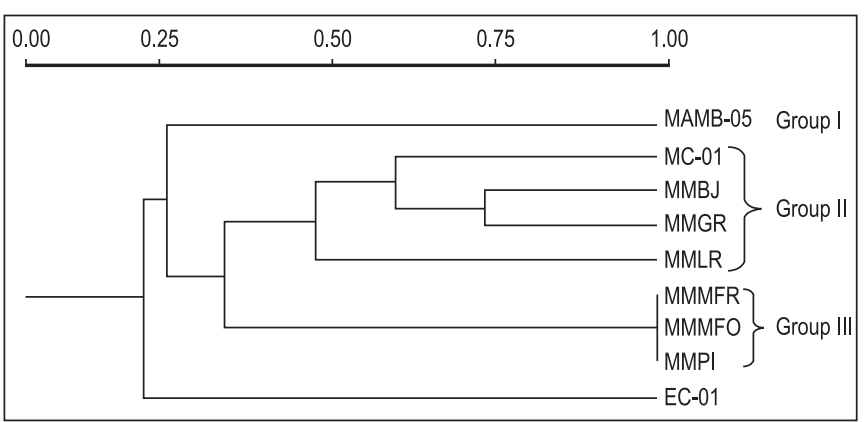

Figure 2. Genetic relationships among the nine isolates of Botryosphaeria based on UPGMA clustering of matrix obtained by the Jaccard similarity coefficient.

correlation with plant host origin and the genetic diversity of the isolates, an observation consistent with that described by Zhou and Stanosz (31). Three clear RAPD groups comprising the $B$. rhodina isolates can be observed (Fig. 2). Group-I, isolate MAMB 05 alone; Group-II, with the highest degree of genetic variation, comprised isolates MC 01, MMBJ, MMGR and MMLR; and Group-III, without variation despite having used 8 primers and comprised isolates MMMFR, MMMFO and MMPI (pinha). Comparison of the RAPD clustering and the enzyme production profiles shows a strong association between the groups and the production of laccase and $\beta-1,3$-glucanase. Groups I and II showed high levels of production of laccase ranging from 0.02 to $0.06 \mathrm{U} / \mathrm{ml}$ (non-induced) and 1.04 to $5.30 \mathrm{U} /$ $\mathrm{ml}$ (induced), as well as greater levels of $\beta$-1,3-glucanase (from 0.45 to $0.70 \mathrm{U} / \mathrm{ml}$ ), while Group-III showed significant lower production levels of these enzymes.

B. ribis strain EC 01 was positioned at an external branch of the tree (Fig. 2) with genetic similarity of $15 \%$ of the B. rhodina isolates group as expected. At the enzyme production levels, $B$. ribis demonstrated a very distinct pattern from the $B$. rhodina isolates, showing a basal level of synthesis of the inducible laccases. The levels of the $\beta-1,3$-glucanase in the absence of VA was higher than that observed for all of the B. rhodina isolates. The reason for the differences in the production of inducible laccase, as well as $\beta$-1,3-glucanase without VA, when compared to the other isolates, have yet to be clarified. In contrast to the laccases and $\beta-1,3$-glucanases, the pectinase production profiles did not show any correlation with genetic diversity. No apparent association could be observed between the groups and the levels of pectinase produced. No correlation could be established with the RAPD tree topology and the plant hosts of the fungal strains. According to Zhou and Stanosz (31), host types or their taxonomic relationships are not necessarily indicative of close relationships among different Botryosphaeria species and associated anamorphic fungi. The reason for this observation is still not clear. 


\section{ACKNOWLEDGEMENTS}

CAPES (Brazil) is acknowledged for financial support and for ProDoc Fellowships to Drs. JE Garcia and LA Vilas-Boas. Dr. RFH Dekker acknowledges CNPq (Brazil) for a senior Fellowship. Dr. MHP Fungaro (Dept. de Biologia Geral) is thanked for access to DNA sequencing. Dr. TL Krugner (Dept. de Fitopatologia da Escola Superior de Agricultura "Luiz de Queiroz", Universidade de São Paulo, Piracicaba-SP, Brazil), and Dr. M Menezes (Dept. de Fitosanidade da Universidade Federal Rural do Pernambuco, Recife-PE, Brazil) are thanked for provision of the different Botryosphaeria isolates.

\section{RESUMO}

\section{Diversidade genética entre isolados de Botryosphaeria e correlação com a produção de enzimas líticas da parede celular}

Nove isolados de Botryosphaeria spp foram avaliados quanto ao crescimento e produção de enzimas líticas da parede celular (lacase, pectinase e $\beta$-1,3-glucanase) quando cultivados em meio basal na ausência e presença do indutor de lacase álcool veratrílico (VA). As relações genéticas entre os nove isolados coletados de diferentes plantas hospedeiras foram determinadas por RAPD. A análise das seqüências de nucleotídeos da região ITS mostrou oito isolados estreitamente relacionados, os quais foram classificados como Botryosphaeria rhodina e um isolado como Botryosphaeria ribis. A análise por RAPD agrupou os isolados em três grupos principais condizentes com os níveis de atividades de lacase e $\beta$-1,3-glucanase. Nenhuma correlação foi detectada entre a produção de pectinase e a diversidade genética nos nove isolados. Entretanto, a linhagem caracterizada como B. ribis, posicionada fora dos grupos principais, se mostrou maior produtora de pectinase na presença de álcool veratrílico.

Palavras chave: Botryosphaeria, ITS e RAPD, Lacase, Pectinase, $\beta$-1,3-Glucanase

\section{REFERENCES}

1. Altschul, S.F.; Gish, W.; Miller, W.; Myers, E.W.; Lipman, D.J. (1990). Basic local alignment search tool. J. Mol. Biol., 215, 403-410.

2. Cunha, M.A.A.; Barbosa, A.M.; Giese, E.C.; Dekker, R.F.H. (2003). The effect of carbohydrate carbon sources on the production of constitutive and inducible laccases by Botryosphaeria sp. J. Basic. Microbiol., 43, 385-392.

3. Alves, A.; Phillips, A.J.L.; Henriques, I.; Correia, A. (2005). Evaluation of amplified ribosomal DNA restriction analysis as a method for the identification of Botryosphaeria species. FEMS Microbiol. Lett., 245, 221-229.

4. Barbosa, A.M.; Dekker, R.F.H.; Hardy, G.E.S.St. (1996). Veratryl alcohol as inducer of laccase by ascomycete, Botryosphaeria sp., when screened on polymeric dye Poly R-478. Lett. Appl. Microbiol., 23, 93-96.
5. Barbosa, A.M.; Steluti, R.M.; Dekker, R.F.H.; Cardoso, M.S.; Corradi da Silva, M.L. (2003). Structural characterization of botryosphaeran: a $(1 \rightarrow 3 ; 1 \rightarrow 6)$ - $\beta$-D-glucan produced by the ascomyceteous fungus. Botryosphaeria sp. Carbohydr. Res., 338, 1691-1698.

6. Bogo, M.R.; Queiroz, M.V; Giménez, D.M.; Azevedo, J.L.; Schrank, A. (1996). Double-stranded RNA and isomeric viral particles isolated from the entomopathogenic fungus Metarhizium anisopliae. Mycol. Res., 100, 1468-1472.

7. Crous, P.W.; Hong, L.; Wingfield, B.D.; Wingfield, M.J. (2001). ITS rDNA phylogeny of selected Mycosphaerella species and their anamorphs occurring on Myrtaceae. Mycol. Res., 105, 425-431.

8. Dekker, R.F.H.; Barbosa, A.M. (2001). The effects of aeration and veratryl alcohol on the production of two laccases by the ascomycete Botryosphaeria sp. Enzyme Microb. Technol., 28, 81-88.

9. Dekker, R.F.H.; Vasconcelos, A.F.D.; Barbosa, A.M.; Giese, E.C.; Paccola-Meirelles L. (2001). A new role for veratryl alcohol: regulation of synthesis of lignocellulose-degrading enzymes in the ligninolytic ascomyceteous fungus, Botryosphaeria sp.; influence of carbon source. Biotechnol. Lett., 23, 1987-1993.

10. Denman, S.; Crous, P.W.; Taylor, J.E.; Kang, J.C.; Pascoe, I.; Wingfield, M.J. (2000). An overview of the taxonomic history of Botryosophaeria, and a re-evaluation of its anamorphs based on morphology and ITS rDNA phylogeny. Stud. Mycol., 45, 129-140.

11. Giese, E.C.; Covizzi, L.G.; Borsato, D.; Dekker, R.F.H.; Corradi da Silva, M.L.; Barbosa, A.M. (2005). Botryosphaeran, a new substrate for the production of $\beta$-1,3-glucanases by Botryosphaeria rhodina and Trichoderma harzianum Rifai. Process Biochem., 40, 3783 3788 .

12. Gordon, D.; Abajian, C.; Green, P. (1998). Consed: a graphical tool for sequence finishing. Genome Res., 8, 195-202.

13. Hall, T.A. (1999). BioEdit: A user-friendly biological sequence alignment editor and analysis program for Windows 95/98/NT. Nucleic Acids Symp. Ser., 41, 95-98.

14. Hseu, R.S.; Wang, H.H.; Wang, H.F.; Moncalvo, J.M. (1996). Differentiation and grouping of isolates of the Ganoderma lucidum complex by random amplified polymorphic DNA-PCR compared with grouping on the basis of internal transcribed spacer sequences. Appl. Environ. Microbiol., 62, 1354-1363.

15. Jacobs, K.A.; Rehner, S.A. (1998). Comparison of cultural and morphological characters and ITS sequences in anamorphs of Botryosphaeria and related taxa. Mycologia, 90, 601-610.

16. Mayer, A.M.; Staples, R.C. (2002). Laccase, new functions for an old enzyme. Phytochem., 60, 551"565.

17. McClendon, J.H.; Somers, G.F.; Heuberger, J.W. (1960). The occurrence of a variety of enzymes hydrolysing cell wall polysaccharides in apples rotted by Botryosphaeria ribis. Phytopathology., 50, 258-261.

18. Rohlf, F.J. (1987). NTSYS-pc: Microcomputer programs for numerical taxonomy and multivariate analysis. Am. Stat., 41, 330.

19. Sambrook, J.; Russel, D.W. (2001). Molecular cloning: A laboratory manual. Cold Spring Harbour Laboratory Press, New York.

20. Silva, E.G.; Borges, M.F.; Medina, C.; Piccoli, R.H.; Schwan, R.F. (2005). Pectinolytic enzymes secreted by yeasts from tropical fruits. FEMS Yeast Res., 5, 859-865.

21. Silveira, R.L.V.A.; Krugner, T.L.; Silveira, R.I.; Gonçalves, A.N. (1996). Efeito de boro na suscetibilidade de Eucalytptus citriodora a Botryosphaeria ribis e Lasiodiplodia theobraomae. Fitopatol. Bras., 2, 482-485

22. Slippers, B.; Crous, P.W.; Denman, S.; Coutinho, T.A.; Wingfield, B.D.; Wingfield, M.J. (2004). Combined multiple gene genealogies and phenotypic characters differentiate several species previously identified as Botryosphaeria dothidea. Mycologia, 96, 83-101.

23. Sneath, P.H.A.; Sokal, R.R. (1973). Numerical taxonomy: The principles and practice of numerical classification. W.H. Freeman, San Francisco. 
24. Somogyi, M. (1945). A new reagent for determination of sugars. $J$. Biol. Chem., 160, 61-68.

25. Stanosz, G.R.; Smith, D.R.; Guthmiller, M.A. (1996). Characterization of Sphaeropsis sapinea from the west central United States by means of random amplified polymorphic DNA marker analysis. Plant Disease, 80, 1175-1178.

26. Thompson, J.D.; Gibson, T.J.; Plewniak, F.; Jeanmougin, F.; Higgins, D.G. (1997). The Clustal X Windows interface: flexible strategies for multiple sequence alignment aided by quality analysis tools. Nucleic Acids Res., 24, 4876-4882.

27. Vasconcelos, A.D.F.; Barbosa, A.M.; Dekker, R.F.H.; Scarminio, I.S.; Rezende, M.I. (2000). Optimization of laccase production by Botryosphaeria sp. in the presence of veratryl alcohol by the response-surface method. Process Biochem., 35, 1131-1138.
28. Vasconcelos, A.D.F.; Dekker, R.F.H.; Barbosa, A.M.; PaccolaMeirelles, L. (2001). Comparison of the laccases, molecular marker proteins, and induction of pycnidia by three species of botryosphaeriaceous fungi. Mycoscience, 42, 543-548.

29. Vogel, H.J. (1956). A convenient growth medium for Neurospora crassa. Genet. Bull., 13, 42-43.

30. White, T.J.; Bruns, T.; Lee, S.; Taylor, J. (1990). Amplification and direct sequencing of fungi ribosomal RNA genes for phylogenetics. In: Innis, M.A., Gelfand, D.H., Sninsky, J.J., White, T.J. (eds.). PCR protocols: A guide to methods and applications. Academic Press, San Diego, CA, p.315-322.

31. Zhou, S.; Stanosz, G.R. (2001). Primers for amplication of mt SSU rDNA, and a phylogenetic study of Botryosphaeria and associated anamorphic fungi. Mycol. Res., 105, 1033-1044. 